\author{
Mykola Dyomin \\ ๑ https://orcid.org/0000-0002-3144-761x \\ Kyiv National University of Construction and Architecture \\ ghok2233@gmail.com
}

Oleksandr Ivashko

๑ https://orcid.org/0000-0002-9194-2153

Kyiv National University of Construction and Architecture

yulia-ivashko@ukr.net

\title{
STREET ART AS A NEW PHENOMENON OF ART - A MEANS OF GENTRIFICATION OF THE URBAN ENVIRONMENT
}

\begin{abstract}
The article deals with the genesis of street art, its transformation from a spontaneous phenomenon of the urban environment, to a phenomenon that has been recognized by the people and professionals and attracted the attention of expert artists. Successively, street art has transformed and is transforming into a specific type of contemporary art, in which various movements of international or regional character (graffiti, muralism) can be determined. The spread of street art as a phenomenon of art was promoted by the availability of information technologies and the activity of manufacturers of aerosol paints. In the process of development of street art, thanks to the participation of professional artists, the art techniques have emerged, which have an interconnection with the classical styles of art. Expanding the scope of application of street art products becomes a significant component of the sphere of spiritual production and requires modern organizational structures and associations, such as art centres and art clusters. It will contribute to the effectiveness of their activities, the popularization of street art as a means of art education of the population, the synthesis of experience. Crystallization of creative processes and thanks to the globalization, their transformation into the directions and styles of street art occur.
\end{abstract}

Keywords: new art, street art, content, art cluster, globalization. 


\section{Introduction}

The issues of determining the meaning of the term "art" as an abstract concept, which is one of the forms of social consciousness and is a specific kind of activity, aimed at describing reality in accordance with the established aesthetic ideals in specified emotional images; the skilful perfection in any field of activity, and the formulation of the criteria for the selection of works of art, - these questions intrigued researchers of different directions; and, moreover, classical theories of art pointed out the existence of the direct relationship between acknowledging the phenomenon as art and the existing works of art, which in this case work as a specific sample or template. However, this is the reason for the contradiction: whence did such a need arise for comparing the new art with the art that is already existing and recognized in the society, since in fact this means that any phenomenon is an art in the case of its historical connection with the recognized previous works and earlier forms of art.

Researchers were interested in the nature of art and they wanted to identify "What is art?"

Accelerating the pace of changes in artistic trends and architectural trends caused by the increasing trends of globalization, the internationalization of society and the development of digital technologies, radically changed the content of the concept of "work of art" itself and translated into art that was not supposed to be art. If in the past centuries, art was primarily a means of aestheticization, then from the first decades of the twentieth century its social context changed: from a method of cultural and aesthetic education, art turns into a peculiar form of sending and transmitting specific information and a particular context from artist to spectators, even in the form of trash or shock.

Changes in the tastes of society are also caused by the rejection by individual sections of society (youth, informal persons, hipsters) of traditional art, which led to the introduction to the rank of art and to the category of artistic work of those works that were not previously considered art - street art (street art), various performances and the like.

At the same time, a change in the meaningful content of the term "art" was also caused by the inability of traditional cultural institutions such as theatres, cinemas, houses of culture, houses of creativity, schoolchildren's palaces to meet the cultural and artistic needs of the present through their limitations of free and unrestricted creative expression.

The reasons for such cardinal changes in the attitude of society to the definition of art were studied primarily by sociologists, political scientists and psychologists since they are based on social factors. 
Experts came to the conclusion that there are common reasons for a change in society's attitude to art and the inclusion of phenomena into categories of art that do not meet the traditional criteria for classifying them as art (for example, street art and graffiti). Such a reason is primarily a psychological reaction of a person to destructive phenomena in modern society and its foreignness to society; in other words, street art and graffiti - this is the desire to express personal "I" in this way, to separate one's "I" from the outside world during the crisis phenomena that tend to increase. ${ }^{1}$ These trends are particularly pronounced in the youth environment, where they become a way of self-expression in the outside world.

\section{The social origins of the new art and the form of its expression}

The globalization of society has led to the strengthening of multiculturalism trends, which has led to the reinforcement of international trends in various spheres of society, including in art. Social processes in society, mentioned at the beginning, led to the fact that phenomena which had not belonged to art before, were introduced to the rank of the art. A striking example is street art, which has evolved from an informal flow into various pictorial techniques; with some degree of conditionality, they can be considered as a particular type of art (murals - painting, graffiti - calligraphy).

The lightning-fast spread of street art, which originated in the 1950s and 60s in New York and covered all countries of the world, prompted researchers from various industries to scientifically analyse this phenomenon, the causes of its occurrence and the specificity of its manifestation. At the same time, traditional methods of analysis used in philosophy, aesthetics, sociology or cultural studies do not provide an objective understanding of the nature of street art, but they widely use the "anonymity" and "protest identification" stamps. It is possible to draw analogies between street art and folk art, which, for example, in Ukraine was expressed in the painting of houses, and in Brazil, there is also a direction of the so-called "Pichaçăo" or "Pishasao".

1 A. A. Antonova, Art clusters as a space for the development of the cultural potential of the city. In the world of science and art: questions of philology, art history and cultural studies: collection of articles. Proceedings of the XLVII Intern. Research and Practical Conf. No. 4 (47). Novosibirsk: Sibak, 2015https://sibac.info/conf/philolog/xlvii/41733 5.05.2018. I. S. Kudriashov, Street art as a phenomenon of modern culture: the problem of genesis and semiotic features of the message. "Criticism and Semiotics", 2014/2.- pp.220-233. D. Luganskaya, Street artist Pavel 183: interview before death (04/04/2013) // BBC Russian Service. URL: http://www.bbc.co.uk/russian/russia/2013/04/130404_-street_art_-p183_- interview.shtml 16.06.2019. 
"Pichaçăo" - the art of drawing stylized inscriptions on the surface of the city, comes from the regions of Săo Paulo and Rio de Janeiro in Brazil, is often described as one of the graffiti varieties or one of the directions that preceded the appearance of graffiti as such. However, the "pixador" themselves - people involved in writing pishasao, consciously separate themselves from the flow graffiti. At first, pishasao emerged in the 60s as a form of the political protest against dictatorship. A little later, when the dictatorship was overcome, the direction of the political pishasao did not disappear, but changed into the writing of romantic texts and quotations on the walls and existed until the early 80s. At that time, a wave of punk rock culture is emerging in Brazil; the popularity of rock groups is growing and the fonts of the logos of these groups amaze local artists, they transform and modify the forms, adapting them to the local culture. On the other hand, the logos of rock groups were created on the basis of the Anglo-Saxon runes, dating back thousands of years. And this ancient culture is transformed through the prism of rock direction and transformed by artists into a unique style. Thus, in a modified form, the pishasao becomes an expression of the artist's ego, the political context disappears and is replaced by the spelling of one's name, that is quite similar to graffiti.

According to the artists, pishasao is aggression directed against society, aggressive conscious intervention in the urban environment by filling large areas with its own stylized font, as much as possible and often. First of all, it is a challenge, adrenaline, the seizure of space. However, even this is dominated by the art component - a considerable amount of time is devoted to creating a unique writing style, which is still based on specific laws of composition and harmony.

Also, as the origins of street art can be considered theses of the manifesto of Russian futurists Decree No. 1 "On the democratization of the arts (fence literature and square painting)", 1918, sponsored by Vladimir Mayakovskii, David Burliuk and A. Kamenskii. It stated: "Comrades and citizens, we, the leaders of Russian futurism, the revolutionary art of youth, declare:

1. From now on, along with the destruction of the royal order, the residence of art in the storerooms, sheds of the human genius - the palaces, galleries, salons, libraries, theatres are cancelled.

2. In the name of the great tread of equality before the culture, the Free Word of the creative person let be written on the intersections of the house walls, fences, roofs, streets of our cities, villages and on the backs of cars, carriages, trams and on the dresses of all people.

3. Let the semiprecious Rainbow spread pictures (paints) on the streets and squares from house to house, pleases, refining the eye (taste) of the passer-by.

Artists and writers are obliged to immediately take pots of paints and brushes of their skill to illuminate, paint all sides, foreheads and chests of cities, 
railway stations and ever-running packs of railway cars. ...

Let the streets be a celebration of art for all."

Often they try to show the continuity of street art and art styles by comparing street art with such forms of cultural and artistic protest as Dadaism, as well as with pop art and land art and, as a conclusion, street art is considered one of the manifestations of modern postmodernism. One can also find a comparison of the street art phenomenon with the urban manifestoes of the situationists of the 1970s since both of these phenomena declared an active exchange of the urban environment. ${ }^{2}$

In these sciences, the principal source of street art is called the social problems of poor neighbourhoods, which in turn caused this form of protest, but this greatly simplifies and narrows the very nature of street art, since social contradictions and protests have existed for a long time, although up to the second half of the twentieth century, they had not appeared in a similar form of expression and the inscriptions on the surfaces of buildings had had advertising or political role. ${ }^{3}$

Only in ancient Rome the planes of urban buildings were used actively to convey particular information, and it was then that the image on the surfaces acted as a means of communication for various purposes - political, advertising, informational, communicative.

A relevant source of art was the invention of aerosol paints in 1949: paint manufacturers actively promoted their popularization, and this impact enhanced by the availability of these techniques and the ease with which they performed.

Basically, in existing sources, sources of street art are called either the social problems of poor neighbourhoods, as manifestations of deviant behaviour without being tied to mysticism, or earlier artistic styles and try to draw parallels between them. These points of view are logical, but not sufficient for a comprehensive understanding of the nature of street art, where, on the one hand, there are social sources, its established philosophy and postmodern ways of transmitting information from an artist to the mass audience.

These individual spontaneous manifestations have expanded in the space of cities, at first, they caused only irritation and negativity of the majority of the population and even more so the city authorities responsible for the aesthetic appearance of the urban environment, therefore repressive measures were applied to the performers. However, later, among the numbers of boring graf-

2 I. S. Kudriashov, op. cit.

3 Ibid. Ye. Perehuda, O. Ivashko, Street art as a factor of cultural development and an element of symbolic politics in post-revolutionary Ukraine. "Stosunki międzykulturowe. Tom 1. Strategie bezpieczeństwa i komunikacji we współczesnym świecie.” Zielona Góra, 2016, p.155-174. 
fiti, the masterful compositions and ideas began to appear; attracted talented artists thought over the volumetric-spatial composition and the colour gamut of wall paintings, and they did not spoil the architecture of the urban space. (Fig. 1). This, in turn, began to attract the attention of art experts who assessed the phenomenon of street art and turned it into a subject of research.

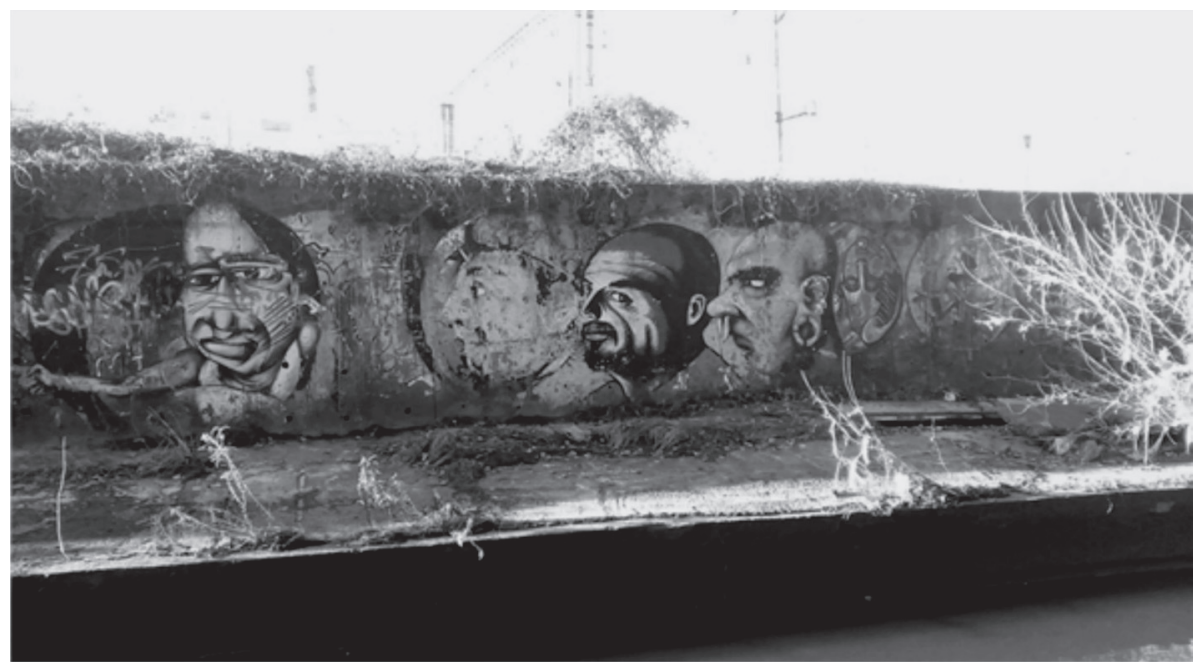

Fig. 1. The example of street art of the 2000s. Kyiv. Photo O. Ivashko, 2018

The main difficulty in assessing the phenomenon of street art as an art form lies in the one-sided analysis of the statements of scholars only and the lack of analysis of the views of artists directly, so to speak, "a look at the phenomenon from the inside".

After analysing different views on the nature of the emergence of street art, we should highlight three of them:

1) the aggressiveness of advertising, causes a negative perception and also protest and at the same time attitude to the work of art as a product that is promoted by the same means of advertising and marketing;

2 ) the aggravation of social contradictions and pessimism in society, the expression of consumer psychology, rendering into protest;

3 ) the emergence and spread of cultural stereotypes in various areas of society and levelling the category of individuality, identity and self-realization, prompted cultural and artistic expression and development of urban spaces by graphics means. ${ }^{4}$

4 I. S. Kudriashov, op. cit. 
Street art, which basically appeared as a spontaneous phenomenon, gradually evolved as art, forming peculiar styles and trends in itself and introducing "author's style" category to the rank of art. So, the staff of artists is also heterogeneous, both uneducated non-professionals and professionals who are positioning their continuous connection with artists of other styles.

Although street art is a fairly widespread phenomenon and encompasses many types of art, there are some principal trends.

The first - graffiti, is one of the initial manifestations of street art and is the application of typeface composition using markers or spray paint on various surfaces. The main idea is to leave your name on more surfaces in the city or to create a unique writing style, which later becomes recognizable. The simplest form of graffiti - tag, takes its official beginning in the 1970s, transforming subsequently due to the struggle for originality in some other styles - throw-up, wildstyle, techno style, blockbuster, 3d, and, in recent years, in calligraphy Each style has own unique features and is distinguished by the rules of writing and the complexity of the drawing. Individually, we should highlight the creation of Characters in letters or separately.

In addition to graffiti, there is a large number of various trends in street art, they are as follows: sticker bombing - applying stickers on the surfaces outside (Fig. 2); various sculptures, sometimes an image from a mosaic spontaneously placed on the walls of houses; installations; murals; yarnbombing - knitted items; posters; seed bombing - planting plants in different places; inscriptions with moss; anonymous photos; flash mobs, etc.

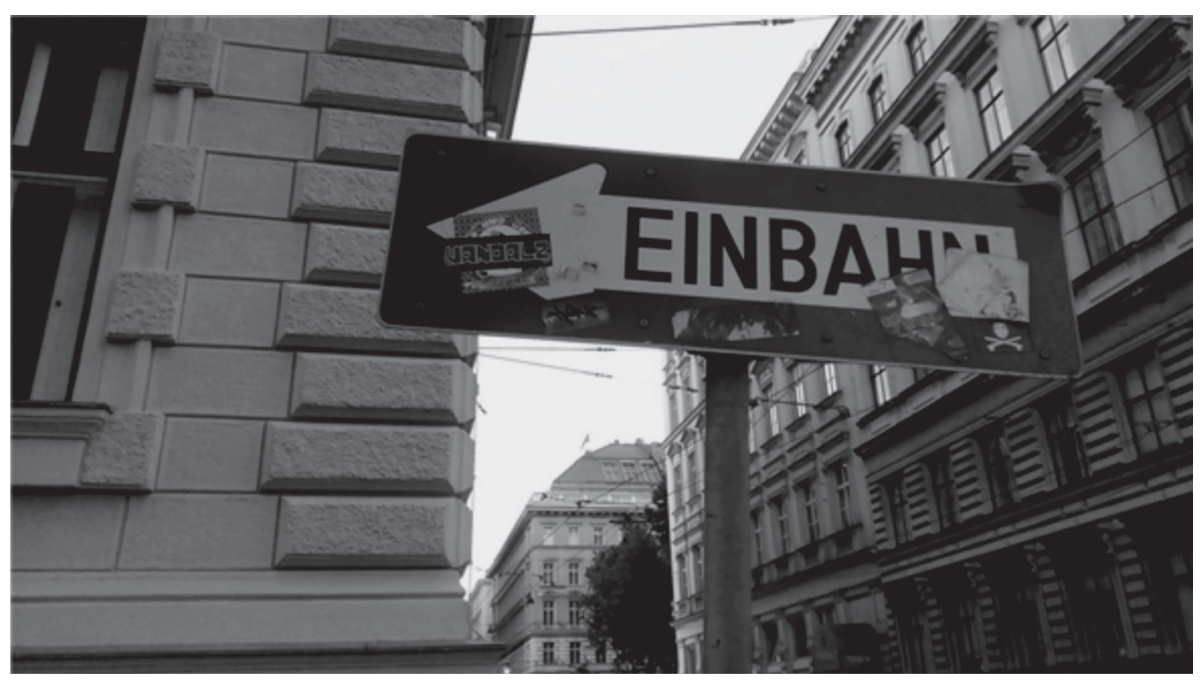

Fig. 2. Stickers on road signs. Vein. Photo O. Ivashko, 2017 
The fact that street art from a spontaneous informal trend gradually turned into a specific type of art is also evidenced by the fact that it gradually formed own philosophy with the declaration of tolerance in the artistic environment and political neutrality. The basis of street art is a dialogue with the audience, the use of space and street art becomes a means of expressing aesthetics, a specific message or carrier of a particular ideology (the so-called "political graffiti"). As well as the new type of multifunctional public art space later, an art cluster, street art becomes not just a new art form that has a significant influence on the formation of the urban environment, along with architecture, but a way for a person to freely express an individual in conditions of in-depth globalization. So, accelerated globalization also has a downside - the "generation gap", strengthening the self-development tendencies without any limits, the separation of one's own identity of both individuals and entire nations through non-traditional ways of self-expression and existence along with the traditional art of "art for the general public", designed for the mass audience.

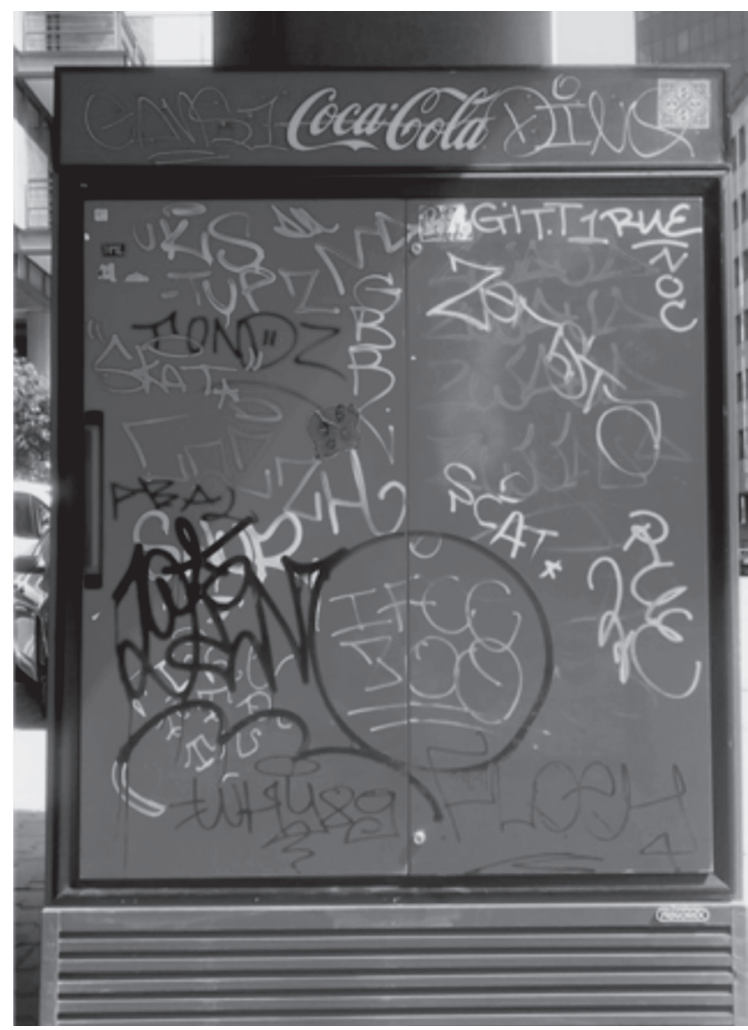

Fig. 3. Graffiti on the street fridge. Warsaw. Photo O. Ivashko, 2018 
The change in tastes against the background of the gap between the aesthetic views of different generations can be visually traced by the example of the most popular type of street art - graffiti (Fig. 3), given the ambiguous assessment of this phenomenon - negative (façade damage, vandalism) and positive (free expression, creative contact between artists through the creation of collective paintings, the development of a specific artistic environment of nonformals). ${ }^{5}$ So, we can give the following assessment of the graffiti phenomenon from the point of view of specialists and the general public:

- from the point of view of psychology and sociology, this is an attempt to assert one's own identity, self-identification (the artist himself creates own pseudonym and executes it with the invented font), an additional method of communication;

- from the point of view of people of the older generation, this is vandalism and damage to the walls, a wrongful phenomenon;

- from the point of view of art, graffiti turned into a modern form of calligraphy, and calligraphy among many nations was even more of a variety of art than painting or engraving (Japan, China, Arabic East), where it was considered the highest manifestation of skill and had a sacred meaning of communication with the divine eternal.

As already mentioned, street art can be a carrier of political ideology, although the philosophy of street art denies it. The so-called "political graffiti" is a response to particular political processes in society. It can be stencilled images, inscriptions of political content. The political murals of the ideological direction are in the same row with the "political graffiti". From this point of view, street art has taken on the socio-philosophical function of monumental art, which in totalitarian countries especially expressed a particular ideology in a way developed for the mass audience.

Street art transformed into several independent kinds: illegal elemental pictures on any surfaces; legally made to order paintings; advertising business; expositions in galleries; "prints".

As already noted, despite the informal nature of the emergence of street art, its varieties can be attributed to the already existing types of art (painting, drawing, calligraphy). It is evidenced that street art has been recognized by society as art by the fact that it is increasingly becoming the subject of researches, monographs, exhibitions and festivals, testifies to the existing public demand for street art in its various manifestations. In a number of cases, a symbiosis of artist-customer-authority arises, when the process of creating street art with spontaneous creativity becomes organized, often within the framework of a specific project agreed by law.

5 Ye. Perehuda, O. Ivashko, op. cit. 
Despite the fact that muralism (muralism from the Spanish Mural - wall, that is, "wall painting") is not an analogue of graffiti, although it also originated from street art, it was in the case of custom murals - monumental painting of surfaces with aerosol paints that less joining them to works of art. These can be large-scale realistic images, close to photographs, abstract and surreal works with grotesque figures and hidden meaning, avant-garde geometrized murals in which the echo of the avant-garde constructivism of the 1920s-1930s is felt; 3D volumetric deconstructivism with placement on planes three-dimensional images (the work of the famous Peeta). Polychrome and monochrome images are most often located on the dead ends of buildings, on the surfaces of fences, even on horizontal planes of roads and pavements that is a means of creating a kind of performance. ${ }^{6}$

It is evidenced that street art gradually acquired signs of art by the fact that its basis is the author's handwriting, which acts as a kind of a "calling card", for example: the artist Peeta received recognition for his one-, four-colour 3D abstractions; Polish artist Przemek Blejzyk is known as an author of grotesque surrealistic, destructive and pessimistic murals; German artist Edgar Mueller (composition "Volcanic Eruption") performs his realistic drawings on the roadway and the sidewalks of the city of Geldern; the Swiss artist Julian Beaver (huge snails, pizza, American eagles, etc.) places his destructive paintings on the sidewalks, squares and roads.

Political overtones have works of street art of the national trend since they appear in those countries where there is a sharp change in social formations. A separate aspect of the study is a way of communication between an artist and a spectator through the artistic and visual means of street art and the semiotics of the information message in street art. Its feature is the use of most of the currently existing methods of conveying information:

1) in scientific sources anonymity of street art is noted, but it is doubtful, since the author's nickname presents him to a limited audience, and some artists deliberately sign and advertise their works and present them at festivals and in galleries; that is, we can speak about anonymity only in some cases of drawings or protest inscriptions, or simply statements;

2) self-presentation is a significant component of street art;

3 ) dependence on Internet technologies, which serve as a means of communication and popularization of works by individual artists, as well as the spread of stylistic trends that immediately become known to the general public and contribute to the internationalization of street art and the writers' artistic community;

6 M. G. Chistyakova, Street art in the context of the challenges of our time. "Izv. Alt. state University » 2011, No.2-1, p. 210-213. 
4) legalization of street art as a result of the liberalization of relevant laws. ${ }^{7}$

So, street art has a direct impact on the formation of the architectural environment. It can be either stylised wall calligraphy, or graphic compositions stylised as comics or realistic, as well as murals, that originated from the street art but now is a separate monumental art.

Thus, a comprehensive analysis of the nature of street art with an overview of the factors of influence and in connection with the art of the past years shows that despite the informal origins and the socio-political nature of this phenomenon, it appeared not from scratch and not from a clean slate, but by essentially replaced the niche that in totalitarian countries was occupied by ideological monumental art, which became widespread because it played the role of visual propaganda for the mass audience (paintings and mosaics on the facades).$^{8}$ It suggests that such a means of aesthetics of space, if necessary, can turn into an ideological subtext, by the method of influencing the mass audience, in fact, is not a fundamentally new phenomenon. It is also not by chance that the murals on the facades that carry a certain ideological content are placed in the central and historical districts of the city, in crowded places, thus contributing to the assertion of a new ideology through visual agitation. At the same time, we should not put the equal mark between the street art and the monumental art of the totalitarian countries, since the ideological component was often dominant in the monumental art: such paintings were placed in certain crowded places; those works, traditionally, were performed on the buildings which represented the particular ideology, in techniques designed for the long-term action (as a rule, mosaics), and in the modern street art, the ideological component is expressed in the context of the specific political processes within society. In countries with no pronounced or hidden social, political, national or religious conflict, works of street art have no political connotations and are a simple means of creative self-expression of artists, non-political works of art.

Besides, the absence of the straightforward equivalence between the monumental art of totalitarian countries and the street art is proved by the fact that monumental art has always been made-to-order, performed by famous artists and approved by expert boards, while street art is more democratic because it is available to anyone, primarily due to the ease of its creation. At the same time, in comparison with the monumental art of the Soviet period, which took into account the particularities of the town-planning design, the style and functionality of the building on which the painting was placed, in modern made-toorder paintings often neither the construction style nor its purpose is taken into

7 I. S. Kudriashov, op. cit.

8 O. V. Shylo, O. D. Ivashko, Monumental art and street art in modern urban space. "Scientific Herald of Construction” 2016 No.2 (84). Kharkiv, p. 74-78. 
account, and it creates some difficulties in the aestheticization of the urban environment.

Multicultural trends in modern street art today are dominant. You can talk about the individual style of the artist, but you cannot talk about the regional originality of most of the murals in the developed European countries, as we find it in the architecture and art of past centuries. As a side note, we should mention that similar trends are now observed in the world architecture, its signs of regionalism mainly disappear and principally natural and climatic features are taken into account.

Manifestations of multiculturalism in modern street art are promoted by holding international festivals, the possibility of contacts with like-minded people from all over the world, and work in teams of people from different countries. For example, the design of the murals on the walls of Kelburn Castle in Scotland was carried out by an international team of writers and was called "The Bridge between Cultures".

The manifestation of regionalism in modern street art is most often associated with the processes of the revival of national consciousness. At the end of the 19th and the beginning of the 20th century, similar trends gave rise to the Finnish "National Romanticism", the Catalan "Modernisme", the Ukrainian modern. Manifestations of regionalism appear where there is a demand for national identity, which is reflected in the scientific publications of Yu.V. Ivashko.

\section{The Artistic methods of aestheticizing the architectural environment in art and architecture}

Modern art tools today significantly affect the aestheticization of the urban environment. At the same time, it is possible to note the similarity of artistic methods of the aestheticization of the architectural environment by means of wall paintings (murals) and supergraphic techniques in architecture. In both cases, applied techniques, super graphics, effects of the destruction of the planes and turning them into a shocking "architectural performance."

At the same time, the murals on the walls and the supergraphics on architectural buildings and constructions differ in the way they are placed: the murals decorate mainly one blind plane, while the supergraphics are placed on several planes and are often broken by window openings or architectural elements.

If we analyse the effect of using super-graphics on the facades of an architecture object, then a work of art (mosaic, painting, super-graphics) simultaneously turns into a method of architectural shaping, as the architect thinks about compositional stylistic integrity, even if it is a shocking object (residential area, 
designed by Hundertwasser). But the artists who create the murals, do not think about the style cohesiveness and consider only the category of a particular object.

So, the difference between muralism and architectural super-graphics on the facades is also in the fact that muralism is not so committed to the stylistic harmony of the architectural environment; it is a more abstract avant-garde direction, which is able with various artistic means to carry to the observer a particular message or a hidden meaning, which is often understood only by the artist. At the same time, in some cases, epatage architects were concurrently avant-garde artists (among other things, Hundertwasser was engaged in the shoe manufacturing, the organization of explicit performances of a particular ideological direction, primarily campaigning for the naturality of any phenomenon).

Akin to the outrageous super graphic art in architecture and the street art is primarily mass, it is the art of the mass Another difference between supergraphics in architecture and murals, lies in the duration of their survival: if supergraphics, in the form of decorations, or in the form of mosaics, is considered by the architect as a part-component of architecture, and it cannot be changed without altering the architecture; the murals on the facades are independent of the architecture and such pictures can be painted over. In cases of similarity of graffiti and muralism, the similarity lies only in the technique of execution (aerosol cans).

Although aerosol cans are now widespread in muralism, such works can also be performed of mosaic, breccia, and ceramic tiles, as was widely applied in the Soviet monumental art. So, it is only possible to compare the murals and architectural supergraphic, while it is impossible to compare graffiti, which are created without a consistent sketch and spontaneously in a random place, with the same works by Hundertwasser. At the same time, the muralism has consistently passed through graphics techniques; therefore, it has grown partially on street graffiti.

A relevant issue for architectural supergraphics, and for muralism, is the choice of colour, where, as a rule, there are several primary and complementary colours. At the same time, in the case of street art, a carefully selected colour palette is primarily inherent in customized murals, wall paintings or works within the art festival, whereas in the case of the elemental mass graffiti, the colour scheme is chosen spontaneously.

The colour scheme of supergraphs of A. Gaudi and Hundertwasser, in the number of colours and their combination can also be inherent in both moral and graffiti, although often in modern works of moralism almost photographic folding images and colours are used. Graffiti, although they can be one-two-colour, most often they are multi-colour, in 1-3 colours, with 1-2 primary colours and several auxiliary ones. 
Thus, a comparative analysis of Friedensreich Hundertwasser's supergraphics with works of contemporary street art makes it possible to note the following:

1) the contrast and the predominance of bright colours. In architectural supergraphic and modern street art dominated by bright contrasting colour combinations designed to attract the attention of the viewer;

2) abstractness and convention of images. The picture sometimes just dissolves in the wall by breaking faces and gradients, often only the author understands the meaning of the painting. Approximately the same abstractions, understandable only to the author, are present in the form of bright stripes and spots on the facades of Hundertwasser and in extravagant colour forms of Gaudi;

3) exaggeration of pictures. Deliberate distortion, scrapping, rounding of faces and lines, hypertrophy of the dimensions of elements and pasture lines, faces, hypertrophy of facade elements with the help of designs and colours in A. Gaudi and Hundertwasser;

4) simplification of details, letters and characters in the style of a comic book in order to provide a drawing of an abstract character; in the architecture of Hundertwasser - the application of simplified geometric elements, the rejection of the pretentiousness of forms;

5) the emphasis of an element. Intentional contrast in murals and architecture in order to identify the accent element or elements.

The need for professional analysis of the phenomenon of street art is determined by several reasons. First, the murals on the walls of houses became so widespread that this process runs the risk of becoming uncontrollable and distorting the urban environment if it is not streamlined. Secondly, the level of such murals is far from the same, among them there are both original and unsuccessful works. Thirdly, the role of such exhibited murals is approaching the part of the architecture and monumental art, as in many cases, wall paintings exist for a long time and are large-scale, therefore, the corresponding requirements should be made to them. Fourthly, in the conditions of the economic crisis, the use of wall paintings can be an alternative to the expensive decoration of facades and interiors, and can also diversify low-aesthetic building.

As the experience of developed countries shows, facade paintings (murals) are increasingly becoming a means of transforming a building into a tourist site. It is possible that the use of unexploited buildings, including historical ones, for holding art festivals of street art, which will help draw attention to them and contribute to the emergence of funds for their maintenance in proper condition.

At the same time, it should be understood that there is a limit to the use of murals on the facades since they must first play the role of a particular accent, 
be single in the line building, take into account the function of the building on which they are located.

For large-scale murals on facades designed for a comprehensive overview, special requirements should be put forward regarding colour and plot. Ideally, they should fit into the surrounding architecture and not resist it.

The state of development of modern street art opens up fundamentally new opportunities for the transformation of the architectural space exclusively by graphics and pictorial methods. The use of street art, especially muralism, seems appropriate when designing the blind end facades of buildings, it allows to diversify the same type of facades, to provide rice integrity of urban development in cases where the image on the facades correspond to the same idea and is stylistically close. In addition, in muralism, especially in 3D-paintings, there is an impression of a particular performance, such murals are most appropriate in amusement parks, recreation areas, playgrounds, etc., while their location on the traffic way is unjustified, because it creates dangerous situations on roads.

Muralism is also reasonable in the interiors of houses of various functional purposes, both in residential and public buildings, one should only consider the purpose of the construction, its characteristics, dimensions, direction, etc. So, if the room is low, you should apply light colours on the walls and blue on the ceiling so that the apartment seems higher and wider; if the room is orientated to the south or southwest, it is better to work with cold colours in its decoration; warm colours draw the walls closer, cold colours distance the walls. Full saturated colours visually diminish the size of rooms.

Moreover, paintings that are appropriate for the façades - in particular, pictures of monsters or scenes of disasters - are hardly desirable in residential or public places; so they often use more neutral abstractions, images of the starry sky, animals, landscapes, etc.

Thus, the following can be noted:

1) street art is gradually turning into a modern mass art, therefore ignoring its distribution is inappropriate, it is worth using it successfully for aestheticization of the urban environment;

2) In Ukraine, the culture of street art is still noticeably inferior to the culture of street art in the United States or some European countries; it also refers to the attitude of the Ukrainian society to the emergence of graffiti and muralism on facades (there are facts when avant-garde or frank murals, even legally drawn, at the request of conservative people, were whitewashed). It should be acknowledged that the advancement of street art to the rank of legal art, the popularization of street art contests, and the engagement of the public in discussing the issues of urban murals, will help to change the attitude to street art as a phenomenon. 


\section{Conclusion}

As the historical experience has proved, art always reflects existing and hidden social processes, and in many cases, it is a harbinger of future changes. Street art has emerged as a socio-political and artistic phenomenon within society, determined by globalization processes and the development of technology, but over time street art obtained specific signs of traditional pictorial art and several specific artistic directions divided from it.

In spite of the widespread opinion that street art owes its origin and spreading out to marginals only, this phenomenon is much more complicated, as, in the course of time, artists with professional education joined to it, and the very phenomenon of street art obtained peculiarities of current art having independent trends and a form of the contemporary advertising business. There is a protest theme in street art - either anti-war, anti-globalization or against air pollution, but not always, sometimes it's just an artist's self-expression without social or political overtones.

A new phenomenon always needs the proper determination of its nature and meaningful content; according to the scheme: a phenomenon - its definition. In the process of the genesis, street art extended its focus: if at first, it acted as an opposition to the established forms of cultural and artistic expression, recognized by society and approved criteria for selection of works of art (museums and galleries), then it began to perform both purely artistic and advertising tasks, it partially moved from the walls to galleries and consumer goods (clothes, accessories).

Art has always acted as a separate segment of culture, or if we use the terminology of political science and philosophy, the superstructure of social relations and a specific form of social consciousness.

The difference in the development of society at the contemporary stage from previous epochs is as follows: the accelerated development, the rapid change of technologies and style trends in architecture and art, the emergence of fundamentally new forms of artistic expression and new types of public art institutions. At the same time, this process gained speed gradually, over millennia, and the change in the period of existence of some styles vividly illustrates it. Meanwhile, pure street art should be separated from street art, which has advanced to the degree of modern urban art. The question of how to reconcile the rejection of street art and the need to take into account the fact of its existence and distribution in modern society becomes relevant.

The processes of globalization have led to the differentiation of types of art. During the historical development of humanity, the number of types of art changed. In parallel with the revision of the categories of "art" and "artwork", the society rethinks the need for artistic institutions since the traditional ones 
no longer fulfilled the requirements of particular strata of the people who are seeking the possibility of free artistic expression and open access to the cultural heritage.

An art cluster replaced the traditional cultural and artistic public association; according to Berys Gaut's theory, an art cluster is a multifunctional public building based on the creative self-expression, which has cultural and business functions, and at the same time it is a free communicative space with a natural combination of numerous various interrelated functions, the total result of the interaction of which significantly exceeds the outcome of their cooperation with each other. ${ }^{9}$ At the same time, it is possible to apply another name for such formations - "creative space", which is a synonym for the term "art cluster", but it is a broader concept, not attached to a specific architectural structure. ${ }^{10}$

It means that there are different types of art, and each of them can develop both autonomously within itself and in connection with other types of art, mutually enriching each other. It is how intraspecific and interspecific relations are formed.

Consequently, the concept of an art cluster assumes that all the components with an art orientation are connected by interconnections; and the total result of their joint action is several times higher than the result of separate components. Thus, the first defining feature of an art cluster as a specific art institution is as follows: it is not just a random set of tenants-carriers of particular types of artistic activity but the presence of tenants or owners who work for one result, and their activities are connected not only in coordinated but also in a functional manner.

For the efficient functioning of an art cluster precisely as a cluster with the opportunity of getting the maximum economic outcome, it is not enough just to give these rooms to various artists, it is necessary to approach the process of solving the art space definitely from the standpoint of clustering, as John L. Mackie and Aaron Meskin stated in their artistic theory ('The Cluster Account

9 M. Orlenko, A. Ivashko, Art-Clusters as a New Type of Buildings: the Specificity of the Spatial Solution and the Features of Restoration during the Redevelopment Process (The Experience of Poland). "Smart Project, Building and City / Środowisko Mieszkaniowe (Housing environment)", 2017, No. 21, Pp. 109-115. N. Fedotova, Creative Cluster in the Context of Socio-Cultural Problems of the Region. All-Russian Scientific and Practical Conference "Challenges of the XXI Century": Materials of the scientific conference. April 30, 2013 Book House "Librokom" 2013, p. 59-68.

10 K. Makarova, Post-industrialism, gentrification and transformation of the urban space of modern Moscow. Neprikosnovennyi Zapas, 2010, Pp. 150-152. M. Martynova, Subjective assessment of the feasibility of basic values in an urban environment and its relationship with the personal potential of university students. "Young Scientist", 2013, No12, p. 809-814. 
of Art Reconsidered ", "INUS Condition " (Unintended but Sufficient Condition). The concept of an art cluster as an interrelated by internal connections art space becomes much more extended than the definition of an art cluster of the SibAK scientific association It essentially imposed restrictions on the concept of art cluster - it is located only on the territory of an industrial zone and includes exhibition space, a showroom, a theatre or cinema venue, auditoriums for workshops, food courts and other elements. In fact, an art cluster becomes a specific artistic quarter with a combination of elements and components of one or several kinds of art but interrelated by the particular activity and result.

\section{BIBLIOGRAPHY:}

Antonova, A.A. Art clusters as a space for the development of the cultural potential of the city. In the world of science and art: questions of philology, art history and cultural studies: collection of articles. Proceedings of the XLVII Intern. Research and Practical Conf. No. 4 (47). Novosibirsk: Sibak, 2015 https://sibac.info/conf/philolog/xlvii/41733 5.05.2018.

Banksy. Existencilism book (2002). URL: http://www.artofthestate.co.uk/banksy/Banksy_Existencilism_book.htm

Daunt, J. The Tactics and Strategies of Banksy and Street Art (2012). URL: http://ru.scribd.com/ doc/104414386/The-Tactics-and-Strategies-of-Banksy-and-Street-Art 16.06.2019.

Ivashko, Yu. \& Ivashko, O. Current issues in research, conservation and restoration of historic fortifications. Chelm-Lviv, 2017. no. 9, pp. 9-14.

Kravchenko, I.L., Ivashko, O.D. The issue of graffiti in the urban environment as a protest form of the youth subculture. "Urban Planning and Territorial Planning" 2014, no. 53, pp. 222-226.

Kudriashov, I.S. Street art as a phenomenon of modern culture: the problem of genesis and semiotic features of the message. "Criticism and Semiotics", 2014/2, pp.220-233.

Luganskaya, D. Street artist Pavel 183: interview before death (04/04/2013) // BBC Russian Service. URL: http://www.bbc.co.uk/russian/russia/2013/04/130404_-street_art_-p183_- interview.shtml 16.06.2019

Makarova, K. Post-industrialism, gentrification and transformation of the urban space of modern Moscow. Neprikosnovennyi Zapas, 2010, pp. 150-152.

Martynova, M. Subjective assessment of the feasibility of basic values in an urban environment and its relationship with the personal potential of university students. "Young Scientist", 2013, no 12, pp. 809-814.

Migunov, A. \& Khrenov, N. S Aesthetics and Theory of Art of the 20th Century [Reader]. M. 2008. 
Orlenko, M., Ivashko, A. Art-Clusters as a New Type of Buildings: the Specificity of the Spatial Solution and the Features of Restoration during the Redevelopment Process (The Experience of Poland). "Smart Project, Building and City / Środowisko Mieszkaniowe (Housing environment)", 2017, No. 21, pp.109-115.

Perehuda, Ye. \& Ivashko, $O$. Street art as a factor of cultural development and an element of symbolic politics in post-revolutionary Ukraine. "Stosunki międzykulturowe. Tom 1. Strategie bezpieczenstwa I komunikacji we wpółczesnym swiecie “. Zielona Gora, 2016. pp.155-174.

Prokofiev, V. N. About art and art history. M., 1985. 161 p.

Tykulov, D. Factories are transformed into art clusters. [Electronic resource] Access mode. URL: http://www.irn.ru/articles/31677.html (appeal date: 03/01/2015). 05.05.2018

Fedotova, N. Creative Cluster in the Context of Socio-Cultural Problems of the Region. All-Russian Scientific and Practical Conference "Challenges of the XXI Century": Materials of the scientific conference. April 30, 2013 Book House "Librokom” 2013, pp. 59-68.

Chistyakova, M.G. Street art in the context of the challenges of our time. «Izv. Alt. state University " 2011, no.2-1. pp. 210-213.

Shylo, O.V. \& Ivashko, O.D. Monumental art and street art in modern urban space. "Scientific Herald of Construction” 2016 no.2 (84). Kharkiv, pp. 74-78.

\section{STREET-ART JAKO NOWE ZJAWISKO W SZTUCE - ŚRO- DEK NA GENTRYFIKACJĘ MIEJSKIEGO ŚRODOWISKA (streszczenie)}

W artykule są rozpatrywane kwestie pochodzenia street-artu, jego transformacji ze zjawiska spontanicznie pojawiającego się w przestrzeni miejskiej na zjawisko, które zyskało uznanie wśród szerokiej publiczności i fachowców oraz przyciągnęło uwagę zawodowych artystów. Street-art stopniowo przekształcił się w specyficzną odmianę współczesnej sztuki. Można w nim zauważyć różne nurty, mające międzynarodowy bądź regionalny charakter (graffiti, muralizm). Rozpowszechnieniu street-artu jako zjawiska sztuki sprzyjała dostępność technologii informacyjnych oraz aktywność producentów farb w sprayu. W trakcie rozwoju street-artu, dzięki udziałowi zawodowych malarzy, ukształtowały się artystyczne chwyty związane z różnymi kierunkami sztuki. Rozszerzenie sfery stosowania street-artu staje się zauważalnym składnikiem produkcji artystycznej i wymaga współczesnych struktur organizacyjnych i związków, takich jak ośrodki i klastery. Będzie to sprzyjało skuteczności działań i popularyzacji street-artu jako środku wychowania estetycznego. Zachodzi też krystalizacja twórczych procesów i ich przemiana na kierunki i style street-artu.

Słowa kluczowe: nowa sztuka, street-art, wypełnienie treścią, klastery artystyczne, globalizacja. 
Dyomin Mykola - PhD in Architecture (1988), Professor (1990), Honored Architect of Ukraine (1997), Corresponding Member of the National Ukrainian Academy of Arts (2001), Professor of the International Academy of Architecture (1992), full member, Vice-President of the Ukrainian Academy of Architecture. In 1975-1986 - Head of the Department of the General Plan of Kyiv; 1988-2002 - Director of the Research Institute of Theory and History of Architecture and Urban Planning.

From 1986 to the present, Head of the Department of Urban Construction of Kyiv National University of Construction and Architecture.

Author of more than 60 significant architectural and urban projects and more than 300 scientific articles. Scientific interests and directions of scientific activity: architecture, urban studies, art theory.

1.Dyomin, M.M., Orlenko, M.I. (2017). The systematic approach to monuments and restoration activities. Urban planning and territorial planning: Scientific and technical collection. Osietrin, M.M. (Ed.). Kyiv, KNUCA. Issue 65, pp.21 -32.

2.Dyomin Mykola, Ivashko Oleksandr. The systematic approach to the revitalization of historical fortifications and industrial enterprises under art clusters. Chelm-Lviv, 2018. No. 10. pp.30-33.

3. Dyomin Mykola, Ivashko Yulia, Rezga Kouider. Mosques of Algeria: Architectural and Urban Aspects. Kyiv, 2019. 192 p.

Oleksandr Ivashko - MA in Architecture, a post-graduate student. Scientific interests and directions of scientific activity: street art, contemporary art, art clusters

1. Ivashko, O.D., Orlenko M.I. Art-Clusters as a New Type of Buildings: the Specificity of the Spatial Solution and the Features of Restoration during the Redevelopment Process (The Experience of Poland). / Środowisko Mieszkaniowe (Housing environment). Kraków, 2017. No. 21. p. 109-115.

2. Iwaszko O. Społeczna Przyroda Nowych Artystycznych kierunków w Miejskim Środowisku. Przestrzeń/Urbanistyka/Architektura, 2/2018, p. 167-176.

3. Ivashko, O., Perehuda, Ye. Street art as a factor of cultural development and an element of symbolic politics in post-revolutionary Ukraine. Stosunki międzykulturowe. Tom 1. Strategie bezpieczeństwa i komunikacji we wpółczesnym świecie. Zielona Góra, 2016. p.155-174.

4. Oleksandr Ivashko. Możliwości użycia sztuki ulicznej we współczesnym dostosowaniu zamków i twierdz. Current issues in research, conservation and restoration of historic fortifications. Chełm-Lviv, 2016. p. 86-90. 